\title{
GLOBAL TOURISM MEASUREMENTS AND RESPONSE TO COVID-19 CRISIS
}

Igor Kovačevićí,

Renata Pindžo²,

Bojan Zečević ${ }^{1}$

${ }^{1}$ Faculty of Economics, University of Belgrade,

Belgrade, Serbia

${ }^{2}$ Ministry of Trade, Tourism and

Telecommunications,

Government of the Republic of Serbia, Metropolitan University, FEFA,

Belgrade, Serbia

\begin{abstract}
:
Pandemics represent a great challenge in tourism development, and as shown by crisis caused by Covid-19, effects are instant and almost totally destructive. This paper provides literature review on influence of medical crisis on tourism, followed by an understanding of economic downturn in tourism in Q1 due to Covid-19.The lLast section of the Paper provides an overview of structure, form and concrete recommendations defined by leading global tourism policy makers and scenarios for tourism re-start.
\end{abstract}

\section{Keywords:}

Covid-19, tourism policies, tourism economics.

\section{INTRODUCTION: \\ INFLUENCE OF MEDICAL CRISIS ON TOURISM}

Various research showed that pandemics do represent a challenge not just for society, but especially for tourism (Hall, 2020; Gössling, 2002), and this was, unfortunately proven, by the research of negative economic impacts (Fan et al., 2018) caused by SARS (Siu and Wong, 2004; McKercher and Chon, 2004), swine flu (Russy and Smith, 2013) and Spanish flu (McKibbin and Sidorenko, 2006). The world is now experiencing a temporary de-globalization, due to heavy travel restrictions and the suspension of international travel that made geographical barriers among places to re-emerge (Niewiadomski, 2020). Covid-19 changed heavily all individuals and industry, but the crisis demonstrated that tourism, hospitality and travel industry are less of a necessity and hence are highly sensitive to significant shocks (Chang et al., 2020).

Although in recent years great performance of global tourism sector was demonstrated in terms of number of tourists, overnight and income (UNWTO, 2020c), the effects of corona virus devastated this sector. In a short period of time global market faced the shift from overtourism (Séraphine et al., 2018; Séraphine et al., 2019; Jover and Diaz-Parra, 2020) to non-tourism and negative impact down the tourism and hospitality value chain (Gössling et al., 2020, pp. 2) and the collapse of the entire sector (Higgins-Desbiolles, 2020, pp. 1).
Correspondence:

Igor Kovačević

e-mail:

igor.kovacevic@ekof.bg.ac.rs 
Covid-19 crisis challenged neoliberal approach, best driven through reducing the government's role and regulations and seen through ideas and attitudes that globalization is an unstoppable fore, while consumerism is the key of expressing our identity. It influenced new forms of government intervention and redevelopment of social caring and networks as a tool used to defend against the crisis (Higgins-Desbiolles, 2020). National institutions and authorities have proven as much more effective in implementing necessary measures in life and economy (Niewiadomski, 2020). However, the question asked is whether the global and national authorities recognized this shocking effect on tourism, and whether the defined measures would support the surviving of tourism and hospitality sector.

In this section the Paper provides an overview over selected global tourism authorities and institutions that were active in the period of global pandemic in a form of providing guidelines, tourism policy measures and tactical support for the recovery of tourism. However, before the overview is discussed, we need to note that the general background of the Paper is that these institutions, as well as national governments, national tourism boards, global hotel chains and aviation were not ready for the crisis of this size. In addition, no crisis management was put properly in place. Those are the reasons why some of the measures are focused on creating crisis management plans, incentivization and recovery packages that could be defined beforehand within tourism strategic development documents and initiatives. However, everyone needs to have in mind that "the measure put in place today will shape the tourism of tomorrow" (OECD, 2020a, pp. 2).

\section{International tourism falldown due to Covid-19}

According to UNWTO (2020a), international tourism in March 2020 showed strong decrease with Asia and Pacific reaching up to -35\% when compared to March 201; and Europe reaching up to - $19 \%$ in the same period with the proven loss of 67 million international arrivals and $\$ 80$ billion in lost exports. However, in April the situation has worsen to a greater extent, especially in Europe and North America, with international traveling being almost entirely stopped, and reaching up to -95\% in comparison to the same time last year. According to STR (2020), hotels in China showed slight recovery at the end of March and in April with occupancy coming back to $+15 \%$ in comparison to January and February when it was almost $0 \%$. According to UNWTO (2020a), as of April $20^{\text {th }}, 100 \%$ of all worldwide destinations have introduced travel restrictions in response to the pandemic, in a form of the following: total or partial closing the borders, totally or partially suspending international flights, and by banning the entry for passengers from specific countries or origin. In addition, based on the research, 86 countries introduced 360 various restrictive policies and restrictive initiatives impacting leisure and business travel market (WTTC, 2020b). Revised studies by OECD (2020a) estimated that total impact will be at the level of $60 \%$ decline for international tourism in 2020 , with potential $80 \%$ decline if recovery is delayed.

\section{International tourism sector recovery recommendations}

In order to support the process of recovery of global tourism, recommendations were introduced in the following areas (UNWTO, 2020b): 1) managing the crisis and mitigating the impact, 2) providing stimulus and accelerating recovery and 3) preparing for the future. Besides various soft development initiatives such as a promotion (WTTC, 2020d), most of the measures in the field of managing the crisis and providing stimulus for recovery and future development can be further classified into the following (WTTC, 2020c): a) fiscal support and tax incentives / reduction / removal, b) protecting human capital and livelihood of workers, c) injecting liquidity \& cash, and d) various forms of recovery funds and investments. In addition to lifting travel restrictions both government and tourism industry should also focus on liquidity support and the preparation of recovery plans, on restoring traveler confidence and stimulating demand with new, safe and clear labels of the sector (OECD, 2020a).

The first and the foremost steps is introducing tools and actions that will help managing the crisis and influence further mitigation of the negative impacts. Having in mind that tourism is a major job creator with 330 million jobs generated around the world, which is 10\% of global employment (WTTC, 2019a), most recommendations are putting employers and employees in the first place in order to save and recover tourism and hospitality companies. 
This group of recommendations includes the following (UNWTO, 2020b):

- Incentivizing job retention, sustaining self-employed and protecting the most vulnerable groups

- Supporting companies' liquidity

- Reviewing taxes, charges, levies and regulations impacting transport and tourism

- Ensuring consumer protection and confidence

- Promoting skills development, especially digital skills

- Including tourism in national, regional and global economic emergency packages

- Creating crisis management mechanisms and strategies

- Providing financial stimulus for tourism investment and operations

- Reviewing taxes, charges and regulations impacting travel and tourism

- Advancing travel facilitation

- Promoting new jobs and skills development, particularly digital ones

- Introducing mainstream environmental sustainability in stimulus and recovery packages

- Understanding the market and acting quickly in order to restore confidence and stimulate demand

- Boosting marketing, events and meetings

- Investing in partnerships

- Introducing mainstream tourism in national, regional and international recovery programmes and in Development Assistance

- Diversifying markets, products and services

- Investing in market intelligence systems and digital transformation

- Reinforcing tourism governance at all levels

- Preparing for crisis, building resilience and ensuring that tourism is a part of national emergency mechanism and systems

- Investing in human capital and talent development

- Placing sustainable tourism firmly on the national agenda

- Transitioning to the circular economy and embracing the SDGs

\section{Tourism re-start scenarios}

Mass tourism will most probably remain a desired target for most destinations, but it needs to be carefully planned (Nepal, 2020). Covid-19 crisis should be used for re-thinking tourism development. Strong tourism growth is a measure reached through a rise in the number of tourists, which on the other hand raise the question of destination carrying capacities and willingness to fully understand needs and wants of those tourists. In addition, destinations need to invest resources in educating tourists about the new experiences approach and sustainability of destination products. Destinations need to learn from their past mistakes of prioritizing quantity over quality, destruction over sensible development, and therefore have in mind that future travelers will have high awareness of environmental health and wellbeing (Nepal, 2020).

In order for tourism to re-start, two components should be taken care of (IATA, 2020, pp. 1): 1) governments must be prepared to allow passengers to travel among countries and regions and 2) passengers must have sufficient confidence that they can travel safely, and achieve what they wish to do during their journey. Nevertheless, prior to lifting travel restrictions health criteria needs to be fulfilled (European Council, 2020): epidemiological criteria, sufficient health system capacity and appropriate monitoring capacity.

In addition to general tourism measures, each service provider along the value chain needs to follow certain global and national standards. In that sense, hotel industry sector needs to implement various measures apart from the obvious health protection measures. It is advised that hotels should develop a Management plan that will include an action plan tailored to the situation and implemented in accordance with the national 
authorities, and mobilization of resources that will allow seamless implementation of the action plan, proper supervision, logbook of actions, clear communication among employees and specific training (WHO, 2020).

According to the implemented measures that have been based on local development levels and the characteristics of tourism, excluding potential additional Covid-19 impacts and waves, the following scenarios have been identified (OECD, 2020a, pp. 3):

- Scenario 1: International tourist arrivals start to recover in July and strengthen progressively in the second half of the year, but at a slower rate than previously foreseen $(-60 \%)$.

- Scenario 2: International tourist arrivals start to recover in September and then strengthen progressively in the final quarter of the year, but at a slower rate than previously foreseen (-75\%).

- Scenario 3: International tourist arrivals start to recover in December, based on limited recovery in international tourism before the end of the year (-80\%)

In response to Covid-19 restrictions of travel and lockdown, tourism businesses (such as hotels and restaurants) are facing new reality in which their standard business model is put to a test. In "traditional" mass tourism destinations, tourism and hospitality service providers were transforming destinations into standardized and homogenous tourist spaces that are serving tourists and visitors, and at the same time differentiating them from local socio-cultural and economic environment (Saarinen 2017, pp. 429). The new reality will strongly challenge them, due to the tendency of making autonomous urban function of entertainment for non-locals (Judd, 2009). This places the destination in a position to choose between locals and tourists and this time making locals potential users of their services (Diaz-Soria, 2017).

During the Covid-19 crisis, hotels looked for alternative ways to reach the desired cash flow and to maintain the service, mostly through food-delivery service, putting them in a competitive set with classical and fast food restaurants which have already been working in that environment. DMC agencies that were focused on corporate events and incentives for foreign clients are in "stand by position", since most of the events have been cancelled or postponed until next year. This challenges their business survival and the level of operations. Professional congress organizers will need to focus on domestic events since international traveling will surely not be in place until September 2020.

\section{CONCLUSIONS}

Domestic travelers and domestic tourism movements are already taking a leading position in the recovery of global position, due to them having a market share of $75 \%$ on average in total tourism economy (OECD, 2020b). However, destinations need to note that domestic travelers, which are either from direct or indirect economic effects, can replace international travelers and international tourism expenditure that is bringing an added value to the economy.

Global tourism policy institutions introduced a number of recommendations and measures that are tackling the crisis. By analyzing them, it can be concluded that most of the measures represent the apparent platforms and paradigms of contemporary functions and development of tourism. We also need to understand that even though one would expect countries and destinations to be using them already, the majority "has forgotten" about basic principles of tourism and increasing competiveness. In addition, during the previous strong period of growth, when tourism reached a record-breaking number, international and national tourism policy makers and influencers did not use the change to position tourism and hospitality as the key economic and social drivers of countries, which can be concluded from the lack of understanding of needed measures in countries.

Tourism in post covid-19 time in the future will be challenging since destinations will need to find new product portfolios that will be putting safety and environmental consciousness in the first place for tourists, while service providers in the value chain will need to implement new formats of business and operations. Global tourism bodies and institutions made great effort in producing various recommendations that will help and assist the re-starting of tourism. 


\section{ACKNOWLEDGMENTS}

Authors acknowledge support from the Ministry of Education, Science and Technological Development of the Republic of Serbia.

\section{REFERENCES}

Chang, C., McAleer, M. \& Ramos, V. (2020). A charter for sustainable tourism after the COVID-19. Sustainability, 12, 3671, 1-4. DOI:10.3390/su12093671

Diaz-Soria, I. (2017). Being a tourist as a chosen experience in a proximity destination. Tourism Geographies, 19(1), 96-117

European Council. (2020). Joint European Roadmap towards lifting COVID-19 containment measures.

Fan, Y. Y., Jamison, D. T., \& Summers, L. H. (2018). Pandemic risk: how large are the expected losses? Bulletin of the World Health Organization, 96(2), 129-134

Higgins-Desbiolles, F. (2020): Socialising tourism for social and ecological justice after COVID-19. Tourism Geographies, 1-14. DOI: 10.1080/14616688.2020.1757748

Gössling, S. (2002). Global environmental consequences of tourism. Global Environmental Change, 12(4), 283-302

Gössling, S., Scott, D \& Hall, C.M. (2020). Pandemics, tourism and global change: a rapid assessment of COVID-19. Journal of Sustainable Tourism, 1-18, DOI: 10.1080/09669582.2020.1758708

Hall, C. M. (2020). Biological invasion, biosecurity, tourism, and globalisation. In D. Timothy (Ed.), Handbook of globalisation and tourism (114-125). Edward Elgar

IATA. (2020). Restarting aviation following COVID-19 - Medical evidence for various strategies being discussed at 09 June 2020 IATA Medical Advisory Group. Retrieved on June 18, 2020, from IATA web site www.iata.org

Jover, J., \& Diaz-Parra, I. (2020). Who is the city for? Overtourism, lifestyle migration and social sustainability. Tourism Geographies, 1-24, DOI:10.1080/14616688.2020.1713878

Judd, D. R. (1999). Constructing the tourist bubble. In D. R. Judd \& S. S. Fainstein (Eds.), The tourist city (35-53). Yale University Press

McKercher, B., \& Chon, K. (2004). The over-reaction to SARS and the collapse of Asian tourism. Annals of Tourism Research, 31(3), 716-719

McKibbin, W. S., \& Sidorenko, A. A. (2006). Global macroeconomic consequences of pandemic influenza. Crawford School of Public Policy, Centre for Applied Macroeconomic Analysis, Australian National University, and Lowy Institute for Foreign Policy

Nepal, S.K. (2020). Travel and tourism after COVID-19 - business as usual or opportunity to reset? Tourism Geographies, 1-6. DOI: 10.1080/14616688.2020.1760926

Niewiadomski, P. (2020). COVID-19: from temporary de-globalisation to a rediscovery of tourism? Tourism Geographies, 1-7. DOI: 10.1080/14616688.2020.1757749

OECD. (2020a). Tourism Policy Responses to the coronavirus (COVID-19). Updated 2 June 2020. Retrieved on June 17, 2020, from OECD web site www.oecd.org/coronavirus

OECD. (2020b). OECD Tourism Trends and Policies 2020. OECD Publishing, Paris, DOI: 10.1787/6b47b985

Russy, D. \& Smith, R. (2013) The economic impact of H1N1 on Mexico's tourist and pork sectors. Health Economics, 22(7), 824-83

Saarinen, J. (2017). Enclavic tourism spaces: Territorialization and bordering in tourism destination development and planning. Tourism Geographies, 19(3), 425-437

Séraphin, H., Sheeran, P., \& Pilato, M. (2018). Over-tourism and the fall of Venice as a destination. Journal of Destination Marketing \& Management, 9, 374-376

Séraphin, H., Zaman, M., Olver, S., Bourliataux-Lajoinie, S. \& Dosquet, F. (2019). Destination branding and overtourism, Journal of Hospitality and Tourism Management, Volume 38, 1-4

STR. (2020). Asian Hotel Review.

Siu, A., \& Wong, Y. R. (2004). Economic impact of SARS: The case of Hong Kong. Asian Economic Papers, 3(1), $62-83$ 
UNWTO. (2020a). UNWTO World Tourism Barometer - May 2020 Special focus on the Impact of COVID-19. Retrieved on June 17, 2020, from UNWTO website https://www.e-unwto.org/doi/book/10.The impact of Covid-19

UNWTO. (2020b). Supporting jobs and economies through travel \& tourism - A call for action to Mitigate the Socio-Economic Impact of Covid-19 and accelerate recovery. Retrieved on June 17, 2020, from thttps:// www.unwto.org/news/unwto-launches-a-call-for-action-for-tourisms-covid-19-mitigation-and-recovery

UNWTO. (2020c). World tourism barometer, Volume 18, issue 1, January 2020

WHO. (2020). Operational considerations for COVID-19 management in the accommodation sector: Interim guidance. 31 March.

WTTC. (2020a). Economic impact report 2019. Retrieved on June 17, 2020, from https://wttc.org/Research/ Economic-Impact

WTTC. (2020b). WTCC Coronavirus: Restrictive Policy Responses \& Governments. Retrieved on June 18, 2020, from https://wttc.org/COVID-19/Member-Hub

WTTC. (2020c). WTTC COVID-19 High Level Enabling Policies document. Retrieved on June 18, 2020, from https://wttc.org/COVID-19/Member-Hub

WTTC. (2020d). Covid-19 related policy shifts supportive of travel \& tourism sector. Retrieved on June 18, 2020, from https://wttc.org/COVID-19/Government-Hub 